\title{
АГРОІНЖЕНЕРІЯ
}

УДК 631.95:631.5:633.1 (477.7)

DOI https://doi.org/10.32848/agrar.innov.2021.7.16

\section{НАПРЯМИ ЕФЕКТИВНОГО ВИКОРИСТАННЯ АГРОЕКОЛОГІЧНОГО ПОТЕНЦІАЛУ ЗОНИ СТЕПУ УКРАЇНИ ТА АДАПТУВАННЯ ТЕХНОЛОГІЙ ВИРОЩУВАННЯ ЗЕРНОВИХ КУЛЬТУР ДО КЛІМАТИЧНИХ ЗМІН}

\author{
ВОЖЕГОВА Р.А. - доктор сільськогосподарських наук, професор, \\ академік Національної академії аграрних наук України \\ https://orcid.org/0000-0002-3895-5633 \\ Інститут зрошуваного землеробства НАAН \\ ДРОБІТЬКО А.В. - кандидат сільськогосподарських наук, доцент, \\ https://orcid.org/0000-0002-6492-4558 \\ Миколаївський національний аграрний університет \\ кокОВІХІH C.В. - доктор сільськогосподарських наук, професор \\ https://orcid.org/0000-0002-1687-6889 \\ Інститут зрошуваного землеробства НАAН \\ пІЛЯРСьКА О.О. - кандидат сільськогосподарських наук \\ https://orcid.org/0000-0001-8649-0618 \\ Інститут зрошуваного землеробства НАAН \\ КАЗАНОК О.О. - кандидат сільськогосподарських наук, доцент \\ https://orcid.org/0000-0002-6817-4985 \\ Херсонський державний аграрно-економічний університет \\ ФЕДОРчУК В.Г. - кандидат сільськогосподарських наук, доцент https://orcid. \\ org/0000-0002-9955-4569 \\ Миколаївський національний аграрний університет
}

Постановка проблеми. Головним завданням рослинництва й землеробства було і залишається створення необхідних умов стійкого ведення сільського господарства на основі інтенсивного використання природних і агрономічних ресурсів, збереження й підвищення родючості ґрунту. В реалізації цього завдання важливе значення мають заходи, що сприяють ефективному використанню земель та забезпечують екологічну рівновагу довкілля [1]. Роль фрактора часу в цих прийомах мас виняткове значення. Стосовно агробіоценозів він виступає у вигляді сукупності окремих процесів, що чергуються за строками їх проведення. Керування тимчасовими показниками (тривалість існування агрофітоценозів та їх елементів; чергування у часі етапів органогенезу, фаз розвитку рослин й інших біологічних процесів, заходів технології вирощування) поєднується в сівозміні, які $\epsilon$ основою систем землеробства [2]. Тому важливе актуальне значення мають дослідження, спрямовані на розробку комплексу заходів з раціонального використання агроресурсного потенціалу степової зони України.

Аналіз останніх досліджень і публікацій. Рослинництво України має вікові фундаторські основоположні наукові й практичні досягнення ефективного господарювання в різних ґрунтово-кліматичних умовах, історія розвитку галузі сфрормувала статус України перед усім як аграрної держави. Сільське господарство України з його базовими галузевими складовими $є$ системоутворюючим у національній економіці, що формує фактори збереження суверенності держави: продовольчу, економічну, екологічну та енергетичну безпеку держави, забезпечує розвиток багатьох галузей національної економіки. Функціонування виробничих систем в аграрному секторі має свої об'єктивні переваги природно-ресурсного потенціалу, спроможного забезпечити потенціал виробництва, що значно перевищує потреби внутрішнього ринку, є галуззю, що на даному етапі стратегічно може стати (у визначених межах) локомотивом розвитку економіки, дати імпульс інвестиційному, технологічному та соціальному піднесенню у державі [3].

Стратегія розвитку рослинництва Степу на подальший період повинна бути спрямована на фрормування, ефективної, ресурсозберігаючої, екологобезпечної, соціально спрямованої, наукоємної галузі економіки держави, здатної у визначених межах задовольнити потреби внутрішнього ринку та провідні позиції експорту рослинницької продукції [4].

Одержання високих і сталих врожаїв сільськогосподарських культур базується на високоефективному використанні ґрунтово-кліматичних ресурсів. У сільськогосподарському виробництві, на відміну від інших галузей народного господарства, ці умови є найважливішими складовими засобами, без чого неможливий сам процес одержання рослинницької продукції. Разом з тим, природні ресурси відрізняються від звичайних засобів виробництва тим, що здатні природним шляхом відновлювати свої властивості, втрачені повністю або частково в процесі використання. При цьому ступінь відновлення властивостей одних видів ресурсів (сонячна радіація, тепло й інші) мало залежать від характеру виробництва продукції, а ступінь відновлення інших (агрофрізична 
структура ґрунту, запаси поживних речовин і продуктивної вологи в ґрунті) визначаються інтенсивністю їх використання у процесі вирощування врожаю [5].

Матеріал і методи досліджень. Метою досліджень було науково обґрунтувати напрями ефективного використання агроекологічного потенціалу зони Степу України та адаптування технологій вирощування зернових культур до кліматичних змін.

При проведенні досліджень використано багаторічні експериментальні дані Інституту зрошуваного землеробства НАAН [6]. Для встановлення показників агроекологічного потенціалу використовували методичні підходи з його розподілом на підсистеми - кліматичний потенціал, потенціал ґрунту, агрогідропотенціал тощо [7]. При цьому ряди показників урожайності (за багаторічними даними Інституту зрошуваного землеробства НААН) інтерполюються до рівня технології заданого року. Дані ряди врожайності, здебільшого статистично однорідні й відповідають закону нормального розподілу. Це дозволяє визначити статистичний максимум урожайності культури та середнє квадратичне відхилення. Значення статистичного (господарського) макси-

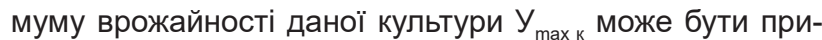
йнято як характеристика агроекологічного потенціалу $\left(\mathrm{AE} \Pi_{\kappa}=\mathrm{Y}_{\text {max к }}\right)$ регіону (господарства) для цієї культури.

Результати досліджень. Агроекологічний потенціал є однією зі складових природно-ресурсного й економічного потенціалу. Він визначається як здатність ґрунтів, атмосфери, гідросфери й біоти регіону давати певну господарську продукцію у конкретних соціальноекономічних умовах використання земель, засновану на біологічній продуктивності, без приведення системи природних ресурсів до необоротного руйнування й різкого погіршення її динамічних якостей.

У кожному господарстві вирощують набір різних культур, кожна з яких має специфічний біолого-генетичний потенціал із властивими їм потребами у фракторах життєдіяльності. Тому стосовно кожної культури регіон має характерний для нього агроекологічний потенціал АЕП .
Значення потенціалу регіону $А Е П_{\text {рег }}$ стосовно всієї одержуваної у регіоні рослинницької продукції може бути отримане як середньозважене значення з величини АЕП. Т. Таким чином, подальше завдання визначення АЕП рег зводиться у визначенні його складових стосовно кожної вирощуваної культури. На практиці АЕП конкретного регіону стосовно певної культури часто виражає вже досягнутий максимум її врожайності: $А Е П=\mathrm{y}_{\max }$. Однак, таке значення врожайності - величина досить випадкова, вона істотно залежить від рівня культури землеробства й не завжди відображує потенційні можливості регіону. Тому необхідно одержати таку кількісну характеристику $A E П_{\kappa}$, що по можливості менше залежала б від рівня технології, оскільки продуктивність агрофітоценозів є результатом багатофакторних зв'язків зі складовими агроекологічного потенціалу. Більш об'єктивним підходом в оцінці $€$ статистичні методи визначення екстремальних значень при обмежених розмірах вибірки.

У степовій зоні України основним чинником , що лімітує реалізацію біолого-генетичного потенціалу сільськогосподарських культур і знижує ефективність агроекологічного потенціалу, є дефіцит вологи. Зрошувальні меліорації значною мірою усувають цей дефріцит і тим самим сприяють збільшенню ефективності агроекологічного потенціалу та ступеню його реалізації у вигляді фактичного рівня врожаю.

Крім загальної оцінки, АЕП становить інтерес розгляд і його окремих складових, зокрема потенціалу клімату. $€$ різні підходи до рішення цього завдання. Розглянемо деякі з них на прикладі кукурудзи.

Загальна оцінка агроекологічного потенціалу може бути виражена в потенційному валовому зборі зерна всіх орних земель регіону або як середньозважене значення статистичного максимуму врожайності. При цьому необхідно мати на увазі нерівноцінність продукції різних культур, вирощуваних у регіоні. Тому пропонується в якості однакового показника продуктивності використати вихід кормових одиниць з гектара ріллі або із всіх орних земель регіону (табл. 1).

Таблиця 1 - Вплив зрошення на реалізацію статистичного (господарського) максимуму урожайності зерна кукурудзи у південних областях України

\begin{tabular}{|c|c|c|c|c|c|c|c|}
\hline \multirow{3}{*}{ Регіон, область } & \multirow{3}{*}{$\begin{array}{c}\text { Тип } \\
\text { землеробства }\end{array}$} & \multirow{3}{*}{ 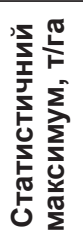 } & \multirow{3}{*}{ 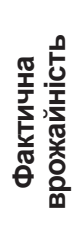 } & \multirow{3}{*}{ 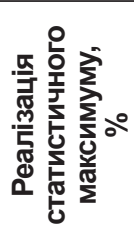 } & \multicolumn{3}{|c|}{ Недобір врожаю } \\
\hline & & & & & \multicolumn{2}{|c|}{ загальний } & \multirow{2}{*}{ 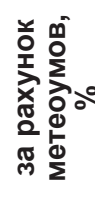 } \\
\hline & & & & & т/га & $\%$ & \\
\hline \multirow{3}{*}{ Запорізька } & зрошення & 5,3 & 3,6 & 58 & 2,7 & 42 & 13 \\
\hline & без зрошення & 4,2 & 1,8 & 43 & 2,4 & 57 & 38 \\
\hline & співвідношення & 0,2 & 0,2 & 1,35 & 0,1 & 0,75 & 0,34 \\
\hline \multirow{3}{*}{ Миколаївська } & зрошення & 4,9 & 3,4 & 30 & 1,5 & 30 & 17 \\
\hline & без зрошення & 3,7 & 1,8 & 49 & 1,9 & 51 & 33 \\
\hline & співвідношення & 0,1 & 0,2 & 1,43 & 0,1 & 0,59 & 0,52 \\
\hline \multirow{3}{*}{ Одеська } & зрошення & 6,1 & 4,2 & 69 & 1,9 & 31 & 13 \\
\hline & без зрошення & 3,9 & 2,0 & 50 & 2,0 & 50 & 31 \\
\hline & співвідношення & 0,2 & 0,2 & 1,24 & 0,1 & 0,62 & 0,42 \\
\hline \multirow{3}{*}{ Херсонська } & зрошення & 6,3 & 4,3 & 69 & 2,0 & 31 & 13 \\
\hline & без зрошення & 3,6 & 1,3 & 36 & 2,3 & 64 & 40 \\
\hline & співвідношення & 0,2 & 0,3 & 1,92 & 0,1 & 0,48 & 0,32 \\
\hline
\end{tabular}


Такий підхід дозволяє одержати більш узагальнену оцінку АЕП, ніж за врожайністю зерна, проте не охоплює повного набору сільськогосподарських культур. Тому загальну оцінку АЕП регіону можна визначити виходом енергії, накопиченої в органах (у ГДж/га) через величину врожаю сухої маси тощо.

Агроекологічний потенціал степової зони України безпосередньо пов'язаний зі змінами клімату, особливо природними гідротермічними умовами на окремих локальних територіях, які можуть суттєво різнити за роками (табл. 2)

За аналізом даних метеорологічних спостережень доведено зміни кліматичних показників Херсонської області мають тісний від'ємний взаємозв'язок коливань середньорічних температур повітря та суми атмоссрерних опадів. Визначено, що за останні 30 років середньорічна температура повітря має сталу тенденцію до збільшення, а у 2019 році досягла максимальних значень $12,9^{\circ} \mathrm{C}$. Опади мають тенденцію до значних коливань, з мінімумом в останні роки 310 мм (2017 р.). Також слід брати до уваги, що збільшення температури атмосферного повітря в різних температурних діапазонах відбувається не рівномірно. Так у 2012 році загальне збільшення суми активних температур склало 19\%, а збільшення суми ефективних температур вище $15^{\circ} \mathrm{C}$ склало 63\%.

Такий розподіл свідчить про надходження на поверхню ґрунту в літній період на 63 \% більшої кількості теплової енергії, що призвело до збільшення середьодекадної температури ґрунту у липні 2012 року на глибині $5 \mathrm{~cm}$ з $26,7^{\circ} \mathrm{C}$ до $31,1^{\circ} \mathrm{C}\left(+4.4^{\circ} \mathrm{C}\right)$, а на глибині $20 \mathrm{~cm}$ з $25,9^{\circ}$ до $29,9^{\circ} \mathrm{C}\left(+4,0^{\circ} \mathrm{C}\right)$, що має безпосередній вплив на продуктивність зернових і зернобобових культур.

В Інституті зрошуваного землеробства НАAН вже тривалий час проводяться наукові дослідження з моніторингу змін регіонального клімату степової зони України. Дослідження показали, що впродовж 135-річного періоду інструментальних спостережень відбувались істотні коливання, як температури повітря, так і кількості опадів у Херсонській області. За цей час відмічалось три періоди потепління. При цьому, сучасне потепління $є$ більш помітним за попередні. Підвищення температури відбувається усі сезони року.

За період досліджень (1990-2019рр.) спостерігається тенденція до збільшення середньорічної температури повітря за даними Херсонського обласного центру 3 гідрометеорології. Швидкість зростання середньорічної температури повітря: у період з 1990 по 1999 рр. складає $0,1812^{\circ} \mathrm{C}$ за рік, у період з 1990 по 2009 рp. $+0,1143^{\circ} \mathrm{C}$ за рік, а з 1990 по 2019 рр. $+0,1134^{\circ} \mathrm{C}$ за рік. За період досліджень (1990-2018рр.) спостерігається тенденція до збільшення середньорічної температури повітря по ГМС "Херсон» за вегетаційний період, що підтверджується рівнянням регресії (рис. 3.4). Швидкість зростання середньорічної температури повітря: у період з 1990 по 1999 рр. складає

Таблиця 2 - Річна сума активних та ефективних температур за 2010-2019 роки (за даними Херсонської агрометеорологічній станції)

\begin{tabular}{|c|c|c|c|c|c|c|c|}
\hline \multirow{2}{*}{ Роки } & \multicolumn{4}{|c|}{$\begin{array}{c}\text { Річна сума } \\
\text { активних температур }\end{array}$} & \multicolumn{3}{|c|}{$\begin{array}{c}\text { Річна сума } \\
\text { ефективних температур }\end{array}$} \\
\hline & понад $0^{0}$ & понад $+5^{0}$ & понад +10 & понад $+15^{0}$ & понад $+5^{0}$ & понад $+10^{0}$ & понад $+15^{0}$ \\
\hline 2010 & $\begin{array}{l}\frac{4443^{*}}{+13 \%^{* *}} \\
\end{array}$ & $\frac{4338}{+17 \%}$ & $\frac{4066}{+21 \%}$ & $\begin{array}{r}3330 \\
+26 \% \\
\end{array}$ & $\begin{array}{r}3142 \\
+21 \% \\
\end{array}$ & $\begin{array}{r}\frac{1892}{+22 \%} \\
\end{array}$ & $\frac{1042}{+40 \%}$ \\
\hline 2011 & $\frac{4060}{+3 \%}$ & $\frac{3795}{+2 \%}$ & $\frac{3534}{+5 \%}$ & $\begin{array}{r}3169 \\
+18 \% \\
\end{array}$ & $\frac{2720}{+4 \%}$ & $\frac{1748}{+13 \%}$ & $\begin{array}{r}\underline{934} \\
+25 \% \\
\end{array}$ \\
\hline 2012 & $\begin{array}{r}4688 \\
+19 \% \\
\end{array}$ & $\frac{4654}{+26 \%}$ & $\frac{4293}{+27 \%}$ & $\frac{3780}{+42 \%}$ & $\begin{array}{r}3388 \\
+30 \% \\
\end{array}$ & $\begin{array}{r}2219 \\
+42 \% \\
\end{array}$ & $\frac{1246}{+67 \%}$ \\
\hline 2013 & $\frac{4385}{+12 \%}$ & $\frac{4120}{+11 \%}$ & $\frac{3466}{+3 \%}$ & $\underline{\underline{3211}}+21 \%$ & $\begin{array}{r}2932 \\
+16 \% \\
\end{array}$ & $\frac{1788}{+15 \%}$ & $\frac{1009}{+35 \%}$ \\
\hline 2014 & $\frac{4386}{+11 \%}$ & $\begin{array}{r}4228 \\
+14 \% \\
\end{array}$ & $\begin{array}{r}3792 \\
+13 \% \\
\end{array}$ & $\frac{3050}{+15 \%}$ & $\frac{2970}{+14 \%}$ & $\frac{1860}{+20 \%}$ & $\frac{1005}{+35 \%}$ \\
\hline 2015 & $\frac{4408}{+12 \%}$ & $\frac{4176}{+13 \%}$ & $\frac{3458}{+3 \%}$ & $\frac{3228}{+22 \%}$ & $\frac{2872}{+10 \%}$ & $\frac{1788}{+15 \%}$ & $\frac{979}{+31 \%}$ \\
\hline 2016 & $\frac{4345}{+10 \%}$ & $\begin{array}{r}4178 \\
+13 \% \\
\end{array}$ & $\begin{array}{r}3710 \\
+11 \% \\
\end{array}$ & $\begin{array}{r}2924 \\
+10 \% \\
\end{array}$ & $\frac{2910}{+11 \%}$ & $\begin{array}{r}1822 \\
+17 \% \\
\end{array}$ & $\begin{array}{r}966 \\
+29 \% \\
\end{array}$ \\
\hline 2017 & $\frac{4507}{+15 \%}$ & $\frac{4275}{+15 \%}$ & $\frac{3625}{+8 \%}$ & $\frac{3262}{+23 \%}$ & $\frac{2956}{+13 \%}$ & $\frac{1826}{+18 \%}$ & $\frac{1016}{+36 \%}$ \\
\hline 2018 & $\begin{array}{r}4419 \\
+12 \% \\
\end{array}$ & $\begin{array}{r}4326 \\
+17 \% \\
\end{array}$ & $\begin{array}{r}4194 \\
+25 \% \\
\end{array}$ & $\begin{array}{r}3420 \\
+29 \% \\
\end{array}$ & $\begin{array}{r}3191 \\
+23 \% \\
\end{array}$ & $\begin{array}{r}2102 \\
+35 \% \\
\end{array}$ & $\begin{array}{r}1127 \\
+51 \% \\
\end{array}$ \\
\hline 2019 & $\frac{4549}{+16 \%}$ & $\frac{4299}{+19 \%}$ & $\frac{3856}{+15 \%}$ & $\begin{array}{r}2924 \\
+10 \%\end{array}$ & $\frac{3017}{+16 \%}$ & $\frac{1868}{+20 \%}$ & $\frac{1031}{+38 \%}$ \\
\hline Середнє & 4419 & 4239 & 3799 & 3231 & 3010 & 1891 & 1035 \\
\hline $\begin{array}{c}\text { Середня багато- } \\
\text { річна норма }\end{array}$ & 3926 & 3705 & 3357 & 2648 & 2604 & 1553 & 746 \\
\hline Відхилення, ${ }^{0} \mathrm{C}$ & +493 & +534 & +442 & +583 & +406 & +338 & +285 \\
\hline Відхилення, \% & +13 & +14 & +13 & +12 & +16 & +22 & +38 \\
\hline
\end{tabular}

Примітка: * - показник;** - відсоток відхилення від середньо багаторічних показників. 
$0,117^{\circ} \mathrm{C}$ за рік, у період з 1990 по 2009 pp. $-0,0839^{\circ} \mathrm{C}$ за рік, а з 1990 по 2019 рр. $-0,0961^{\circ} \mathrm{C}$ за рік. За період досліджень (1990-2019рр.) спостерігається тенденція до незначного збільшення середньорічних опадів та зменшення середніх опадів.

Відмічаються високі температури, вище багаторічних середніх значень, які негативно впливають на продуктивність сільськогосподарських культур. В такі періоди збільшується випаровування з поверхні ґрунту та зменшується відносна вологість повітря, що призводить до термічного опіку рослин. Тривала спека послаблює процеси фотосинтезу і відповідно зменшує кількість органічної речовини та урожайність сільськогосподарських культур. Підвищення температури повітря та нерівномірний розподіл опадів, які мають зливовий, локальний характер у теплий період і не забезпечують ефективне накопичення вологи у ґрунті зумовило збільшення кількості та інтенсивності посушливих явищ.

Слід зауважити, що найбільш загальна оцінка агроекологічного потенціалу може бути отримана якщо статистичний максимум урожайності всього комплексу культур виразити через економічні показники (чистий прибуток, собівартість, рентабельність, тощо).

В таблиці 3 наведені багаторічні результати досліджень вчених Інституту зрошуваного землеробства НААН щодо впливу строків сівби на урожайність основних сільськогосподарських культур (у даному випадку пшениці озимою).

Встановлено, що найбільш сприятливими строком сівби був - 25 вересня, оскільки він відмічається і найвищою врожайністю пшениці озимою. Збільшення тривалості вегетаційного періоду, зростання суми температур за вегетаційний період, надходження ФАР та сумарного випаровування, зростання нестачі води для задоволення потреб рослин вимагає збільшення площ зрошення шляхом відновлення колишніх зрошувальних систем та будівництвом нових. Розширення площ поливних земель потребує значних витрат водних ресурсів, дефіцит яких загострюється як в Україні, так і у світі. Крім того, вони розподіляються дуже нерівномірно.

Для протидії кліматичним викликам необхідно розробляти і впроваджувати інноваційні технології вирощування сільськогосподарських культур, системи мінімізації обробітку ґрунту (No-Till, Mini-Till), відновлювати лісосмуги для збереження вологи ґрунту й попередження процесів водної і вітрової еро- зії, фрормувати науково обґрунтовані сівозмін, а також відновлювати і розширювати зрошення.

3 метою зменшення негативного впливу сільського господарства на навколишнє природне середовище шляхом мінімізації викидів парникових газів у процесі виконання технологічних операцій при вирощуванні зернових і зернобобових культур необхідно передбачити інноваційні системи основного обробітку ґрунту з метою збереження вуглецю у ґрунті та природної його вологи; знижувати вуглецеву ємність сільського господарства; впроваджувати органо-мінеральні системи удобрення та біологічних елементів регулювання росту й розвитку рослин.

Для підвищення обсягів виробництва зерна та іншої рослинницької продукції необхідно сконцентрувати дослідження в аграрній галузі за двома напрямами:

І. Підвищення ефективності використання зрошуваних земель на засадах інтенсифікації технологій вирощування, нормування ресурсів тощо;

II. Максимальне збереження та раціональне використання опадів і ґрунтової вологи у технологіях вирощування на неполивних землях, біологізація агротехнологій, оптимізація систем обробітку ґрунту, удобрення та захисту рослин (рис. 1).

Нашими розрахунками встановлено, що за оптимального режиму зрошення рівень сприятливості агрометеорологічних умов для росту й розвитку кукурудзи на зерно коливається за період 1970-2018 рр. від 0,42 до 1,49, при середньобагаторічному значенні 1,0 (рис. 2).

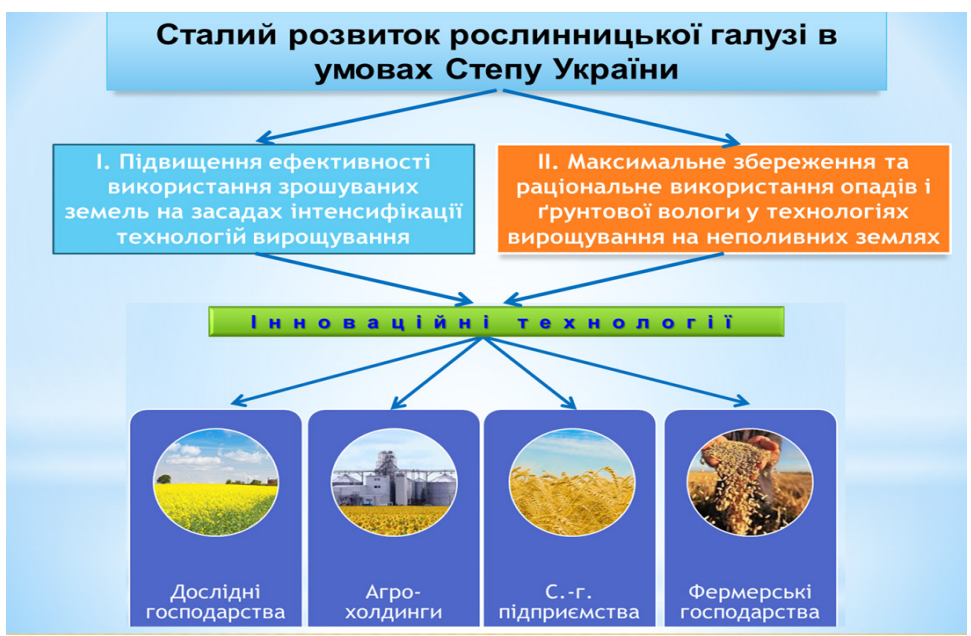

Рис. 1 Напрями сталого розвитку рослинницької галузі в умовах Степу України для адаптування до кліматичних змін

Таблиця 3 - Урожайність пшениці озимої залежно від строків сівби на дослідних ділянках Інституту зрошуваного землеробства НАAН, т/га

\begin{tabular}{|c|c|c|c|c|c|}
\hline Строки сівби & 1967-1984 pp. & 1997-2000 pp. & 2001-2005 pp. & 2006-2010 pp. & 2011-2015 pp. \\
\hline 5.09 & 4,15 & 3,71 & 4,60 & 4,38 \\
\hline 15.09 & 4,34 & 4,03 & 5,08 & 4,84 \\
\hline 25.09 & 4,35 & 3,70 & 5,09 & 5,01 \\
\hline 5.10 & 4,05 & 3,41 & 4,10 & 4,79 \\
\hline 15.10 & 2,81 & 2,57 & 3,36 & 4,77 & 3,73 \\
\hline
\end{tabular}




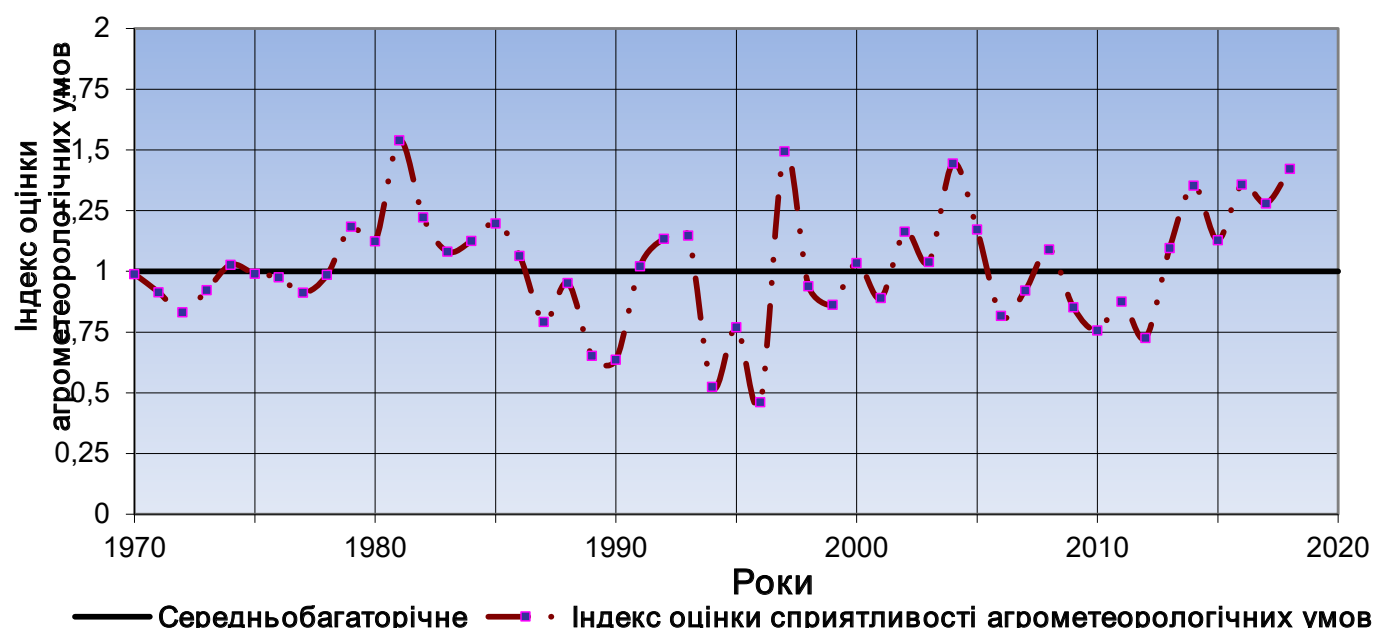

Puc. 2. Індекс оцінки агрометеорологічних умов вегетації кукурудзи на зерно

Значні коливання індексу оцінки агрометеорологічних умов викликані річними коливаннями окремих метеорологічних показників. Статистичне моделювання показує, що найбільш сприятливі погодні умови складалися у періоди 1980-1983, 1991-1993, 1997, 2004, 2018 рр. У зазначені роки спостерігалося підвищене надходження атмосферних опадів та помірний термічний режим. Навпаки, у 1994-1996, 1998-1999 і 2006-2007 рр. відмічене різке зниження продуктивності кукурудзи внаслідок надзвичайно високих температур повітря, різкого дефіциту природного зволоження, суховіїв тощо. За останні роки (2014-2018рр.), внаслідок сприятливих погодних умов - продуктивність кукурудзи - підвищується.

Висновки. Таким чином, з метою мінімізації впливу зміни клімату на сільськогосподарське виробництво степової зони України необхідно розробити й впровадити напрями адаптації сільськогосподарського виробництва до різних сценаріїв кліматичних змін, зокрема системи землеробства з ресурсоощадними, ґрунтозберігаючими елементами технологій, інноваційними системами обробітку ґрунту для зниження антропогенного навантаження на ґрунт та зменшення викидів парникових газів, удосконаленими системами захисту рослин від хвороб та шкідників, використанням адаптованих до посушливих умов і зрошення сортів і гібридів сільськогосподарських культур, а також культур з коротким періодом вегетації, попередження процесів деградації ґрунтів, засолення й осолонцювання та водної і вітрової ерозії, запровадження водозберігаючих режимів зрошення та інноваційних способів поливу сільськогосподарських культур. Визначено, що ефективність реалізації високого природно-кліматичного потенціалу зони Степу України обмежується підвищенням посушливості клімату. В зв'язку з цим, стратегічні завдання аграрного сектору економіки повинні бути спрямованими на збільшення продуктивності ріллі, економію енергетичних ресурсів, покращення родючості ґрунтів, зменшення антропогенного навантаження на навколишнє середовище 3 метою забезпечення збалансованого природокористування. За результатами узагальнення багаторічних даних вставлено, що максимальна врожайність зерна гібридів кукурудзи різних груп стиглості формується у вологі роки, а найменша - у сухі, причому рослини найкраще використовують теплоенергетичний потенціал зони півдня України у вологі та середньовологі роки, що пояснюється найвищою інтенсивністю продукційних процесів. За допомогою одержаних рівнянь регресії можна проводити вибір найбільш оптимального гібридного складу для регіональних та локальних агрокліматичних умов Південного Степу України. За результатами досліджень встановлено різні ступені мінливості метеорологічних та агрономічних показників. Використання статистичних методів дозволило провести оцінку років досліджень за індексом сприятливості агрометеорологічних умов та встановити регресійні рівняння продуктивності рослин.

\section{СПИСОК ВИКОРИСТАНОЇ ЛІТЕРАТУРИ:}

1. Вожегова Р. А., Коковіхін С. В., Дробітько А. В., Найдьонов В. Г. Вплив агрозаходів на ефективність використання соєю фотосинтетично активної радіації та вологи в умовах півдня України. Таврійський науковий вісник. Херсон, 2021. Вип. 117. С. 122-127.

2. Кіріяк Ю. П., Коваленко А. М., Біляєва І. М., Федорчук М. І., Коковіхін С. В. Дослідження змін температурного режиму за багаторічний період у південно-степовій зоні України та вивчення його впливу на продуктивність пшениці озимої. Таврійський науковий вісник. 2017. Вип. 97. С. 53-59.

3. Коковіхін С. В. Науково-методичні основи встановлення закономірностей та розробки математичних моделей формування урожаю польових культур при зрошенні: монографія. Херсон: Айлант, 2010. 246 с.

4. Коковихин С. В., Биднина И. А., Шарий В. А., Червань А. Н., Дробитько А. В. Оптимизация агротехнологического процесса возделывания сельскохозяйственных культур на орошаемых землях с использованием информационных технологий. Почвоведение u агрохимия: научный журнал. 2020. № 2(65), июль - декабрь 2020 г. Минск: Институт почвоведения и агрохимии. С. 63-71. 
5. Вожегова Р. А., Коковіхін С. В., Біляєва І. М. Адаптування систем зрошуваного землеробства до локальних та регіональних умов Південного Степу України та глобальних змін клімату. Таврійський науковий вісник: наук. журнал. Херсон: Грінь Д.С., 2017. Вип. 98. С. 29-35.

6. Ушкаренко В. О., Нікішенко В. Л., Голобородько С. П., Коковіхін С. В. Дисперсійний і кореляційний аналіз у землеробстві та рослинництві: навч. посібник. Херсон : Айлант, 2008. 272 с.

7. Лимар А. О., Лимар В.А., Коковіхін С. В. Домарацький $€$. О. Агрокліматичні ресурси півдня України та їх раціональне використання: монографрія. Херсон: Грінь Д.С., 2015. 246 с.

\section{REFERENCES:}

1. Vozhehova, R.A., Kokovikhin, S.V., Drobitko, A.V., \& Naidenov, V.G. (2021). Vplyv ahrozakhodiv na efektyvnist' vykorystannya soyeyu fotosyntetychno aktyvnoyi radiatsiyi ta volohy $v$ umovakh pivdnya Ukrayiny [Influence of agricultural measures on the efficiency of soybean use of photosynthetically active radiation and moisture in the conditions of the south of Ukraine]. Tavriyskyy naukovyy visnyk - Taurian Scientific Bulletin, 117, 122-127 [in Ukrainian].

2. Kiriyak, Yu.P., Kovalenko, A.M., Bilyayeva, I.M., Fedorchuk, M.I., \& Kokovikhin, S.V. (2017). Doslidzhennya zmin temperaturnoho rezhymu za bahatorichnyy period u pivdenno-stepoviy zoni Ukrayiny ta vyvchennya yoho vplyvu na produktyvnist' pshenytsi ozymoyi [Investigation of temperature changes over many years in the south-steppe zone of Ukraine and study of its effect on winter wheat productivity]. Tavriyskyy naukovyy visnyk - Tavriyskyy naukovyy visnyk - Taurian Scientific Bulletin, 97, 53-59 [in Ukrainian].

3. Kokovikhin, S.V. (2010). Naukovo-metodychni osnovy vstanovlennya zakonomirnostey ta rozrobky matematychnykh modeley formuvannya urozhayu polovykh kultur pry zroshenni: monohrafiya [Scientific and methodical bases of establishment of regularities and development of mathematical models of formation of a crop of field cultures at irrigation: monograph]. Kherson: Aylant [in Ukrainian].

4. Kokovikhin, S.V., Bidnina I.A., Shariy, V.A., Chervan, A.N., \& Drobitko, A.V. (2020). Optimizatsiya agrotekhnologicheskogo protsessa vozdelyvaniya sel'skokhozyaystvennykh kultur na oroshayemykh zemlyakh $s$ ispolzovaniyem informatsionnykh tekhnologiy [Optimization of the agrotechnological process of cultivation of agricultural crops on irrigated lands using information technologies]. Soil science and agrochemistry: Scientific journal, 2(65), 63-71 [in Russian].

5. Vozhehova, R.A., Kokovikhin, S.V., \& Bilyayeva, I.M. (2017). Adaptuvannya system zroshuvanoho zemlerobstva do lokalnykh ta rehionalnykh umov Pivdennoho Stepu Ukrayiny ta hlobalnykh zmin klimatu [Strategy for the development of agriculture systems of the Southern Steppe of Ukraine to changes in the regional climate]. Tavriyskyy naukovyy visnyk - Taurian Scientific Bulletin, 98, 29-35 [in Ukrainian]
6. Ushkarenko, V.O., Nikishenko, V.L., Holoborodko, S.P., \& Kokovikhin, S.V. (2008). Dyspersiynyy i korelyatsiynyy analiz u zemlerobstvi ta roslynnytstvi: navch. posib. [Analysis of variance and correlation in agriculture and crop production: a textbook]. Kherson: Ailant [in Ukrainian].

7. Lymar, A.O., Lymar, V.A., Kokovikhin, S.V. \& Domaratsky, E.A. (2015). Ahroklimatychni resursy pivdnya Ukrayiny ta yikh ratsionalne vykorystannya: monohrafiya [Agroclimatic resources of the south of Ukraine and their rational use: monograph]. Kherson: Grin D.S. [in Ukrainian].

Вожегова Р. А., Дробітько А. В., Коковіхін С. В., Пілярська О. О., Казанок О. О., Федорчук В. Г. Напрями ефективного використання агроекологічного потенціалу зони Степу України та адаптування технологій вирощування зернових культур до кліматичних змін

Агроекологічний потенціал $є$ однією зі складових природно-ресурсного й економічного потенціалу. Він визначається як здатність ґрунтів, атмосфери, гідросфери й біоти регіону давати певну господарську продукцію у конкретних соціально-економічних умовах використання земель, засновану на біологічній продуктивності, без приведення системи природних ресурсів до необоротного руйнування й різкого погіршення її динамічних якостей. Метою досліджень було науково обґрунтувати напрями ефективного використання агроекологічного потенціалу зони Степу України та адаптування технологій вирощування зернових культур до кліматичних змін. Методи. Польові досліди проведено згідно з методикою дослідної справи та спеціальних методик зі встановлення агроекологічного потенціалу. Результати. Визначено, що ефективність реалізації високого природно-кліматичного потенціалу зони Степу України обмежується підвищенням посушливості клімату. В зв'язку з цим, стратегічні завдання аграрного сектору економіки повинні бути спрямованими на збільшення продуктивності ріллі, економію енергетичних ресурсів, покращення родючості ґрунтів, зменшення антропогенного навантаження на навколишнє середовище з метою забезпечення збалансованого природокористування. Висновки. За результатами узагальнення багаторічних даних вставлено, що максимальна врожайність зерна гібридів кукурудзи різних груп стиглості фрормується у вологі роки, а найменша - у сухі, причому рослини найкраще використовують теплоенергетичний потенціал зони півдня України у вологі та середньовологі роки, що пояснюється найвищою інтенсивністю продукційних процесів. За допомогою одержаних рівнянь регресії можна проводити вибір найбільш оптимального гібридного складу для регіональних та локальних агрокліматичних умов Південного Степу України. За результатами досліджень встановлено різні ступені мінливості метеорологічних та агрономічних показників. Використання статистичних методів дозволило провести оцінку років досліджень за індексом сприятливості агрометеорологічних умов та встановити регресійні рівняння продуктивності рослин.

Ключові слова: зрошення, агроекологічний потенціал, зернові культури, агрозаходи, індекс оцінки агрометеорологічних умов. 
Vozhehova R.A., Drobitko A.V., Kokovikhin S.V., Pilyarska O. O., Kazanok O. O., Fedorchuk V. G. Directions of effective use of agroecological potential of the Steppe zone of Ukraine and adaptation of technologies of cultivation of grain crops to climate change

Agroecological potential is one of the components of natural resource and economic potential. It is defined as the ability of soils, atmosphere, hydrosphere and bioty of the region to provide certain economic products in specific socio-economic conditions of land use, based on biological productivity, without bringing the system of natural resources to irreversible destruction and sharp deterioration of its dynamic qualities. The aim of the research was to scientifically substantiate the directions of effective use of agroecological potential of the Steppe zone of Ukraine and adaptation of grain growing technologies to climate change. Methods. Field experiments were conducted in accordance with the methodology of research and special methods for establishing agroecological potential. Results. It is determined that the efficiency of realization of high natural-climatic potential of the Steppe zone of Ukraine is limited by the increase of climate aridity. Therefore, the strategic objectives of the agricultural sector of the economy should be aimed at increasing crop productivity, saving energy resources, improving soil fertility, reducing anthropogenic pressure on the environment in order to ensure sustainable use of nature. Conclusions. According to the results of generalization of long-term data it is inserted that the maximum grain yield of maize hybrids of different maturity groups is formed in wet years, and the lowest - in dry, and plants best use the heat potential of southern Ukraine in wet and medium wet years, due to the highest intensity of production processes. Using the obtained regression equations, it is possible to select the most optimal hybrid composition for regional and local agroclimatic conditions of the Southern Steppe of Ukraine. According to the results of research, different degrees of variability of meteorological and agronomic indicators have been established. The use of statistical methods allowed to estimate the years of research on the index of favourable agrometeorological conditions and to establish regression equations of plant productivity.

Key words: irrigation, agroecological potential, grain crops, agro-measures, agrometeorological conditions assessment index. 